\title{
Exploring the Theological and Practical Implications of Contextualization Among Muslims
}

\author{
Dikko Bature Darma \\ Department of Islamic Studies, Umaru Musa Yar'adua University, Katsina, Nigeria. \\ dikko.bature@umyu.edu.ng
}

DOI: https://doi.org/10.22452/usuluddin.vol49no1.8

\begin{abstract}
The greatest missionary challenge throughout the church history is ministering to the Muslims. Previously, different approaches have been employed by the church with different settings; however, they yield little or no results at all. The need to address the challenge of Islam is ardent among Christian missionaries: therefore, in their struggle to propagate Christianity among Muslims as well as to maintain its diminishing number of followers, missionaries have been in search of new methods for Muslim outreach. Their newest discovery is the contextual approach that has been much debated in so many theological books and journals that explain its theological and practical implications. However, the methods of contextualization are said to have been successfully employed for missionary activities in some parts of the Muslim world and it has imparted to the Christian mission further significance and validity. To this end, at some level contextualization was rather accepted in regards to outreach to Muslims. This paper attempts to discuss the theological and practical implications of this new method of 'contextualization' in its various approaches and to see the element, if any, that distinguishes it from the former missiological methodologies of 'Inculturation,' 'Identification,' 'Indigenization' or 'Vernacularization' etc.
\end{abstract}

Keywords: Contextualization, Theology, Methods, Muslims, Christians and Implications.

\section{Introduction}

Contextualization as a term is coined to describe a way to counter the so many challenges that result in the inability of the individual Christian and the local Church to cope and grow. One of these factors is the resurgent political power of Islam. ${ }^{1}$ In other words, contextualization is theorized due to the fact that reaching Muslims is among the most difficult tasks of modern church and the

1 Richard W. Eagle, "Contextualization in Missions: A Biblical and Theological Appraisal" Grace Theological Journal, Vol.4, no.1 (1983), 86. 
subsequent failure of missionary work among Muslims in the last fourteen centuries. Houssney writes:

Missionaries began to discover that there were many barriers that needed to be surmounted and that communicating the Gospel to Muslims was extremely challenging. Until recently, the missionary movement has been unsuccessful in most Muslim lands. Churches were small and weak and tended to draw membership from historical churches rather than from Muslim communities. ${ }^{2}$

In a broader meaning, the term is described as an aspect of cross-cultural propagation of the gospel. ${ }^{3}$ Louersdorfs gives different meanings to the term 'contextualization', among others, "Contextualization is the process whereby the message of the Word of God is related to the cultural context of the society to which it is proclaimed." He, therefore, summarizes its object as, "God's Word is to be brought to people where they live, in the cultural soil in which they are rooted, so that they can identify with it, feel at home in it, and express themselves with it in their own cultural forms." Hence, the term contextualization means an act of adapting Christianity to the custom, culture and identity of a given people. It is a realization of the fact that people can easily be evangelized by way of identification with their culture and lifestyle.

In the context of Christian mission, the term contextualization was first used in the early 1970 's, ${ }^{5}$ and defined as the theological

2 Georges Houssney, "Position Paper on the Insider Movement," website Journal of Biblical Missiology, http://biblicalmissiology.org/2010/05/03position-paper-on-insidermovement, 3 .

3 Georges Houssney, "Position Paper on the Insider Movement," website Journal of Biblical Missiology, 107.

4 Richard E Louersdorfs, "Contextualization of the Gospel, What are the Implications of Our Work?" (World Mission Conference, East Fork, Arizona August 6-10, 1984).

See http://essays.wisluthsem.org:8080/bitstream/handle/123456789/2905/Lauers dorfGospel.pdf?sequence $=1$ \&isAllowed $=y$

5 As Travis points out that, "literature applying contextualization theory to outreach among Muslims began to appear in the 1970s. Early important articles came from Anderson (1975), Wilder (1976), Kraft (1979), and Conn (1979). Four landmark books concerning contextualization among Muslims came out before 1990: The Gospel and Islam (ed. McCurry 1979), New Paths in Muslim Evangelism (Parshall 1980), Beyond the Mosque (Parshall 1985) and Muslims and Christians on the Emmaus Road (ed. Woodberry 1989). 
process many non-Western churches were going through of reinterpreting the Gospel in terms of their own culture and situation in time. ${ }^{6}$ However, in Evangelical mission circle it refers to an effort to solve the problem related to the resistance of Muslim societies to the Gospel mission in the public domain. ${ }^{7}$

Though, the series of definitions could be extended considerably, let us review some literature related to the contextualization.

\section{Literature Review}

To begin with Ishtiyaq ${ }^{8}$ his article serves an excellent introduction to the subject matter of Contextualization. He remarks that the high population growth rate in Muslim countries as well as the worldwide resurgence of Islam in recent years has deeply disturbed Christian organizations, leading them to devise Contextualization, ${ }^{9}$ which means to preach the Gospel to Muslims in the religious context of Islam. But, according to him, the differences in the fundamental beliefs and world views of both Islam and Christianity reveal that to contextualize the Gospel message in Muslim society will either lead to sheer syncretism or the further distortion of Christianity. Therefore, his conclusion is that contextualizing Gospels' message into Islamic culture is not because the Islamic faith merits such esteem and veneration to Christianity, but because it is an unavoidable necessity for genuine communication of the

These books and articles, along with the advent of new classes and seminars taught at colleges and churches, meant that by the 1990s, cross-cultural sensitivity and some level of contextualization was fairly widely accepted in regards to outreach to Muslims." See, John and Anna Travis, "Contextualization among Muslims: A Focus on "Insider Movements" in Appropriate Christianity (William Carey Library Publishers, 2005).

6 John Stringer, "Contextualization: Transformational Trialogue," St Francis Magazine, June 2007, No 1. Vol. III, P2, website http//:www.stfrancismagazine.info

7 John Stringer, "Contextualization: Transformational Trialogue," 3.

8 Ishtiyaq Danish, "Contextualization: A New Missionary Approach to Muslims," al-Tawhid, Vol. 5, no. 3 \& 4. Website www.alislam.org/altawhid/context.htm

9 Ishtiyaq Danish, "Contextualization: A New Missionary Approach to Muslims," 1. 
Gospel message to Muslim peoples. In the same way Parshall ${ }^{10}$ views contextualization as an inevitable tool for Muslim evangelism. He argues that Christian witness demand pushing forward to new frontiers; that gospel must operate within the context of Muslim for it to yield any fruit. However, the main focus of his book is on how to apply contextualization to the 'orthodox Muslims' which he describes as the Muslims living in a rural area in a country that is predominantly Islamic. The book contained three parts. Most importantly part I and II discuss the Principles of Contextualization and Application of Contextualization respectively. However, the rest of other issues discussed in part III are not much relevant to this paper. Robin ${ }^{11}$ like Parshall, his target group is popular Islam which he called 'Folk Islam.' According to him, previous techniques such as debate, dialogue, community centers, literature, and relief work have not been effective. Therefore, he proposed some measures to reach Muslims by contextualizing according to their world-view, since apologetic approaches both confrontational (e.g., polemic) and nonconfrontational (e.g., dialogue) have not resulted in any breakthrough in Muslim Evangelization. In addition, Harley's article $^{12}$ points out some seven ways, Bible translation as the foremost, that Christians can approach the task of contextualization and believing that it will enhance Church Planting Movement among Muslims. "Church planting cannot be contextualized without a translation geared to Muslims." 13 He points that Christians desirous of communicating Christ to Muslims need to use the distinctively Islamic language for at least two reasons. The first is for identification i.e., to at least be "as a Muslim to the Muslim"14.

10 Phil Parshall, Muslim Evangelism: Contemporary Approaches to Contextualization (Waynesboro-USA: Gabriel Publishing, 2013).

11 Robin Dale Hadaway, "Contextualization and Folk Islam: A Case Study of Sudan," (PhD Thesis, University of South Africa, 2010).

12 Harley Talman, "Islam, Once a Hopeless Frontier, Now? Comprehensive Contextualization," in International Journal of Frontier Mission, retrieved on $15^{\text {th }}$ www.ijfm.org/PDFs IJFM/21_1_PDFs/06_12_Harley3.pdf.

13 Harley Talman, "Islam, Once a Hopeless Frontier, Now? Comprehensive Contextualization," 1.

14 Harley Talman, "Islam, Once a Hopeless Frontier, Now? Comprehensive Contextualization," 7. 
Secondly, Islamic language is needed for clear communication. This can help to reach out to those who are disillusioned or fed up with Islam or who are attracted to Western or Christian lifestyle.

John Travis' C1-C6 scheme proposed a descriptive categorization of the contextualization of the Gospel into Islamic culture that was published in Evangelical Mission Quarterly (EMQ) in October 1998. ${ }^{15}$ The overriding idea in the scheme propagates that instead of trying to get Muslims into the Church, Jesus should be brought into the Mosque. That would allow Muslims, who decide to become Christians to stay within the fold of Islam, what they termed as Insider Movement. Whereas traditional mission in the Muslim world did not lead to mass conversion, it is hoped that this approach might create a larger harvest. ${ }^{16}$ In analyzing this scheme, Stringer, on the other hand, proposed a contextualized missiology for different cultural settings other than sticking to a uniform scheme as that of Travis. ${ }^{17}$ On the other hand, somewhere John Travis makes points on his model that is referred to as the C1-C6 spectrum $^{18}$. He stressed on the issue of the fellowship of 'Muslim followers of Jesus' (the C-5 position on the scale) as the best in the Muslim world today. Because, in his words; "We have little hope in our lifetime to believe for a major enough cultural, political and religious change to occur in our context such that Muslims would become open to entering Christianity on a wide scale". ${ }^{19}$ Then, he tried to answer some questions that arise from theological perspectives such as: Can a person be truly saved [Christian] and continue to be a Muslim? Doesn't a follower of Christ need to identify himself as a Christian and officially join Christian faith? Can a Muslim follower of Christ retain all Muslim practices, in

15 John Travis, "The $\mathrm{C} 1$ to C6 Spectrum: A Practical Tool for Defining Six Types of Christ-centered Communities (C) Found in the Muslim Context" in Evangelical Mission Quarterly (October 1998), pp. 407- 408, P. 6.

16 John Travis, "The C1 to C6 Spectrum: A Practical Tool for Defining Six Types of Christ-centered Communities (C) Found in the Muslim Context," 7.

17 John Stringer, "Contextualization: Transformational Trialogue," St Francis Magazine, June 2007, No1. Vol. III, website http//:www.stfrancismagazine.info

18 John and Anna Travis, "Contextualization Among Muslims, Hindus and Buddhist: A Focus on Insider Movement," Mission Frontier, SeptemberOctober 2005, website www.misionfrontiers.org

19 John and Anna Travis, "Contextualization Among Muslims, Hindus and Buddhist: A Focus on Insider Movement," 2. 
particular, prayer in the Mosque toward Mecca and continuing to repeat the Muslim creed? He framed answers to these questions around ten premises all in positive. He further emphasized that beyond Islam, this is applies to other religious faiths such as Hindus and Buddhist and then concludes that, "the process may be theologically messy, but we see no alternative." 20

Jim Leffel ${ }^{21}$ tries to explain to the mission organizations, the nature and extent of contextualization among Muslim. He argued that while contextualization is interpreted as "allowing them to follow Christ and remain within their own culture," 22 personal identity and culture, on the other hand, are inseparable from religious tradition and belief. Therefore, such contextualization model is tantamount to religious syncretism. He, therefore, suggests the consideration of some key elements of Islamic religious tradition, belief, and practices in terms of prayer, fasting and almsgiving as to what extent can they be incorporated into Biblical faith and practice. Chastain shares similar view with Jim Leffel as he also tries to explain how to avoid syncretism when applying contextualization. ${ }^{23}$ Although, his focus is solely on "Salat" as some Christian workers perform it even at home and in private because they consider it to be an improvement on traditional Christian form, he generally condemned any act done to appeal human nature in a double-minded manner. He gave fifteen reasons why Christians are prohibited from such an act. Therefore, in his opinion, this new legalism will eventually lead to contention, confusion in the Church, and compromise of faith. Thus, he called on Christians not give up their heritage in the name of contextualization. Although, there are some reservations about his article concerning Islam, of all literature reviewed, his view about the issue of contextualization stands unique as it highlights on the Christian polemics of contextualization.

20 John and Anna Travis, "Contextualization Among Muslims, Hindus and Buddhist: A Focus on Insider Movement," 3.

21 Jim Leffel, "Contextualization: Building Bridges to the Muslim Community," website Xenos Christian Fellowship, retrieved on 20 August 2013, www.xenos.org/...ds/OnlineJournal/issue1/contextu.htm

22 Jim Leffel, "Contextualization: Building Bridges to the Muslim Community," 1.

23 W. C. Chastain, "Should Christians Pray the Muslim Salat?"International Journal of Frontier Mission, Vol. 7, no. 2 (JUL-SEP. 1995): 161. 
With this background, let us further investigate the facts and motives behind contextualization in the following paragraph.

\section{Facts and Motives of Contextualization}

It is a commonly acknowledged fact that Islam is the fastest growing religion in the world today, whereas the matching numerical increase in Christianity has been very low over so many years. ${ }^{24}$ Furthermore, Muslim communities prove unwelcome to Christians than others. While Christian missionaries can hardly win converts, their adherents easily become converted to Islam. The high number of converts to Islam and the ongoing worldwide resurgence of Islam become a source of concern to the Christians missionaries. Therefore, they start to devise new ways of reaching out to Muslims, which lead to this new development. Danish writes:

Reportedly, Muslims have increased in the last fifty years by 235\%, whereas the corresponding increase in the Christian world has been $47 \%$ figure which includes the statistical Christian of the capitalist world as well as the population of the Eastern European countries of the communist bloc. The high population growth rate in Muslim countries as well as the world-wide resurgence of Islam in recent years have deeply disturbed Christian's organizations, leading them to devise new missionary approaches to Muslims. One of such approaches which is more an anti than evangelism, is 'contextualization'. ${ }^{25}$

The truth of this assertion can be ascertained in many writings of the Christian evangelists. Missiologist John Travis considers the process of contextualization as inevitable despite its many theological implications because there is "no alternative," 26 i.e. contextualization was inevitable because of the lack of alternative methods for the Christian missionaries as well as the need to propagate Christianity. Emetuche declares that "Christians have

24 Ishtiyaq Danish, "Contextualization: A New Missionary Approach to Muslims," al-Tawhid, Vol. 5, No. 3 \& 4, website www.alislam.org/altawhid/context.htm.

25 Ishtiyaq Danish, "Contextualization: A New Missionary Approach to Muslims,"1-2.

26 John and Anna Travis, "Contextualization among Muslims, Hindus and Buddhist: A Focus on Insider Movement." 
been generally frustrated in their efforts to reach Muslims for Jesus Christ. ${ }^{27}$ Hence, there is a need for indigenous, evangelistic, and culturally relevant church to emerge in the Islamic world-view. That is why, Parshall in his book, ${ }^{28}$ challenged traditional missionary approaches to Muslims as unproductive and proposed some ideas of contextualization that are currently accepted in principle by the mainstream Christian mission.

However, on the other hand, there are some missionaries who regard contextualization as a mere apology on the part of Christians. Waldrep mentions of an Iranian Christian leader who observes that, "When it comes to Islam, the issue of contextualization is sometimes taken too far .... In the beginning we fought with them [the Muslims], then we ignored them, and now there is a tendency to appease them." 29 We shall see later that some Orthodox Christians will completely reject contextualization and paint it unbiblical.

\section{Review of Some Related Terms of Contextualization}

Contextualization is, no doubt, a new mission terminology. However, its roots are found in other theological concepts of Christian missiology. Therefore, it can be said that the word "contextualization" had gone transformation of meanings until 1970's when it became the discourse of theological research and reflection. Some related terms formerly used are as follow:

Indigenization: Indigenization and contextualization have a similar referent. The latter, however, has a wider meaning than the former. Indigenization in Christianity can be defined as the process of making indigenous churches to operate in line with the cultural and traditional norms of a given environment, against the usual alienation of churches from Western culture and tradition.

According to Ishtiyaq Danish, the concept of the indigenous church came to the fore in the nineteenth century when Christianity

27 Damian Emetche, "The Challenge of Discipling Muslim Background Believer," website Global Missiology, retrieved on 30 October 2014, www.GlobalMissiology.org

28 Phil Parshall, Muslim Evangelism: Contemporary Approaches to Contextualization. Revised Edition of New Paths in Muslim Evangelism (1980).

29 Richard Brent Waldrep "Contextualization and Church Planting," (Dissertation, The Southern Baptist Theological Seminary, 2007), 11. 
was severely criticized as white man's religion in Africa and misjudged because of their concept of foreignness by people in Asia. As the Africans and Asians were required to embraced the brand of Christianity of Europe by denouncing their culture and with the local churches under the control of the white foreigners, who were obsessed with their racial superiority and experience in colonial administration, the aforesaid Afro-Asian criticism contained a great deal of truth. Some clergy who were disturbed by such 'allegations' determined to bring some dignity to the national and regional churches, conceived the idea of an indigenous church. ${ }^{30}$ As such, indigenization means that a Church should adopt a form of thought and mode of action that are natural and familiar to the people in a given environment. Therefore, those indigenous churches that are re-thinking about the implication of the gospel to reflect their own culture emerged as a result of indigenization. However, the major distinguishing element in the concepts of contextualization and indigenization is the motive. While indigenization attempts to reconstruct church tradition among Christian followers, contextualization engages in constructing and developing a theology that makes Christianity relevant to a targeted group of people.

Identification: This term refers to the way of communicating in Christian missionary activities. It requires style and format of a language of an evangelist to be familiar to the recipient. ${ }^{31}$ At times, "Identification" is used interchangeably with the term "Vernacularization". In a nutshell, it is a method of conveying the message of the gospel in a term and concept familiar to the target audience. This principle teaches Christian missionaries to communicate to every people group in its own idiom (language and culture). Talman writes that:

Workers desirous of communicating Christ to Muslims need to learn the distinctively Islamic language for at least two reasons. The first is for identification. It would seem to me even those who are calling themselves 'Christian' and identifying with the

30 Ishtiyaq Danish, "Contextualization: A New Missionary Approach to Muslims."

31 Andy Warren-Rothlin "Bible Translation and Evangelism in West Africa," Paper presented at the Kenya Translation Seminars, Pan-Africa Christian College (PACC), and all Saints Cathedrals, Nairobi, Kenya (June 2006), 6. 
ethnic Christian community could at least be "as Muslim to the Muslim" when he is in conversation with him. Many times, Muslims asked if I was a Muslim, simply because I was talking like one. My experience was that the Muslim appreciates the Christian who convey respect for his culture and identifies with his heritage in this way. As a result, hearts were open and eager to hear my message. Secondly, as noted above, Islamic language is needed for clear communication. Many Christian words are unknown or unclear to the Muslim and the use of Christian language can raise psychological and emotional barriers against the message. ${ }^{32}$

Therefore, Identification is closely related to Indigenization, which simply means nativism and the process of domestication of the Gospel..$^{33}$ Both concepts emerged out of the belief that people respond quickly and positively when they are addressed in their own cultural idioms. Hence, theyurge for "Identification" in the process of evangelism among Muslims.

Inculturation: It simply means to make the Gospel message more intelligible in the idioms of the language and culture of the receivers. Inculturationis a term used in Christianity, especially in the Roman Catholic Church, referring to the adaptation of the way Church teachings are presented to non-Christian cultures, and to the influence of those cultures on the evolution of these teachings when around the year $50 \mathrm{CE}$, the apostles convened the first Church council, the Council of Jerusalem, to decide whether to include Gentiles and inculturate Gentile culture. The Council confirmed that Gentiles could be accepted as Christians without first converting to Judaism. This means to present the teachings of Christianity to the Gentiles in their own cultural norm. Meanwhile, Inculturation is a way in which local churches understand, express and live according to their own particular cultural geniuses. ${ }^{34}$ Therefore, Inculturation aims at making the church so homely and

32 Harley Talman, "Islam, Once a Hopeless Frontier, Now? Comprehensive Contextualization," 7.

33 Augustus ChukwumaOhajiriogu, "Religion in the Context of African/Igbo Migration from the Pre-Colonial Times to the Contemporary Period" (PhD. Thesis, University of Wien, 2009), 193.

34 S.J. Marcello Dec Azevado, "Workshop: Inculturation and the World Church". See website file://C:/Users/User/Downloads/3190Article\%20Text-5308-1-10-20130104\%20(1).pdf 
local, more than ever in each particular culture where the Gospel is preached. The sense is to create a situation whereby the Church is allowed to be able to grow not only in recognition but also in allegiance and cooperation with the entire community. ${ }^{35}$ Thus, underlying the word Inculturation is the problem of how to relate faith and culture. ${ }^{36}$

However, Inculturation is different from Enculturation and Acculturation as both terms are used in the mission context. Enculturation corresponds to the more familiar sociological and psychological term, socialization that denotes the process by which a human person is introduced to and becomes inserted into his/her own culture. While, Acculturation as an anthropological concept means the encounter with a culture other than one's own or the contact between cultures and the change such contact provokes. ${ }^{37}$ Therefore, most of the contextualization processes discussed in this chapter adopts the process of Acculturation.

Another relative term, Adaptation, gives the impression of intrinsic missionary activity like a missionary men or women wearing a dress in a closing of the target group, keeping full beard that corresponds to the appearance of a religious Muslim, observing Muslim dietary practices and so on. ${ }^{38}$ The term closely related to adoption of missionary activities is Accommodation, which gives an impression of syncretic practices. However, it does not assume clear theological discussion or interpretation to warrant our discussion on it.

\section{The Implications of Contextualization as an Evangelical Approach}

When the issue of contextualization first appeared around the turn of the last century, it was promoted through different models by the western educated Christian missiologists. So many missionary workers among Muslims were fascinated by it, and it was widely

35 Augustus ChukwumaOhajiriogu, "Religion in the Context of African/Igbo Migration from the Pre-Colonial Times to the Contemporary Period," 193.

36 S.J. Marcello De C Azevado, "Workshop: Inculturation and the World Church," 2 .

37 S.J. Marcello De C Azevado, "Workshop: Inculturation and the World Church," 2.

38 Phil Parshall, Muslim Evangelism: Contemporary Approaches to Contextualization (Waynesboro-USA: Gabriel Publishing. 2013), 28. 
distributed. Much has been written that discussed the application of contextualization in ministering Muslims, especially in the 1990's. However, while some Evangelists are content on the issue of contextualization, the concern that some other Christians have is the fact that they feel the issue of contextualization crosses line and falls into religious syncretism.

Contextualization originates, according to the view of its advocates, from the activity of the early church. St. Paul, for instance, demonstrated a contextual approach when establishing Christianity; he preached that "Everyone should remain in the state in which he is called." $39 \mathrm{He}$ further repeated, 'So, brethren, in whatever state each was called, there let him remain with God'. ${ }^{40}$ They interpret this to mean Christian convert can continue in a religious tradition where the Lordship of Jesus or Jesus as the Son of God is not recognized. Ishtiyaq Danish summarizes the historical meaning of the above biblical verses, in the following words;

As the Jews were reluctant to give up their Law, Paul did not demand that they abandon it. Instead, he acknowledged their world-view and invited them to believe in Jesus without abandoning the Torah. He dealt with the Gentiles in a similar way when he took the Gospel to them. The Law and other Jewish traditions were absolutely repugnant to the pagans; so Paul abolished the Law for the sake of conversion. He held that Biblical Christianity was not related to any particular culture. The basic Christian truth is one: faith in Christ. Whoever accepts this truth enters the Christian fold, whatever his culture. $^{41}$

Therefore, the on-going trend of contextualization is very much in line with Paul's thinking: Paul, in his earnest desire to win converts to the new religion of Christianity adopted contextual methodology, at the expense of the original teachings of the Christ. He struggled to break Christianity from its Jewish cultural trapping to enter the Greco-Roman world of the Gentiles. In doing so, he violated so many laws and traditions that changed the entire theology.

\footnotetext{
391 Corinthians 7:20.

401 Corinthians 7:24.

41 Ishtiyaq, 4. Ishtiyaq Danish, "Contextualization: A New Missionary Approach to Muslims."
} 
Another point used to justify contextualization is the bitter experience of resistance that Christians have, throughout history, with regards to getting Muslims to accept Christianity. Travis and companion confess that:

We have little hope in our lifetime to believe for a major enough cultural, political and religious change to occur in our context such that Muslims would become open to entering Christianity on a wide scale. But we do have great hope, as great as the promises of God, to believe that an "insider movement" could get off the ground. ${ }^{42}$

An examination of the "Insider Movement" reveals that the view of God, Christ, and the gospel of its proponents are impacted. ${ }^{43}$ They are the ones propagating the idea that instead of getting Muslims to the church, Jesus should be brought into the mosque. Insider movement is a contextualization process that allows those who consider Jesus as their Lord and Saviour to stay inside their Muslim culture, inside their biological family, continue to proclaim themselves Muslims, therefore, believe the "shahada" (there is no God but Allāh and Muhammad is His messenger), continue to go to the mosques attempt to pray five times a day, participate in the Ramadan fast, and some believe can go on the Pilgrimage to Makkah. In short, it allows Muslims who decide to become followers of Jesus to stay within the fold of Islam, just as Messianic Jews have stayed within Judaism.

That is why the orthodox Christians that are conscious of the above theological implication of the concept of contextualization reject the idea totally and raise the following important observations.

Taking into consideration some basic differences in the fundamental beliefs and world-views of Islam and Christianity, the contextualization of the Gospel message among Muslims cannot be done without syncretism, distortion or compromise of the teaching of Christianity. For instance, Islam believes in an uncompromising monotheism per excellence, whereas Christianity, which claims its roots from the Jewish monotheistic religion, has drifted into a trio: God the Father, the Son and the Holy Spirit. Therefore, Christian

\footnotetext{
42 John and Anna Travis, "Contextualization among Muslims, Hindus and Buddhist: A Focus on Insider Movement," 14.

43 Georges Houssney, "Position Paper on the Insider Movement."
} 
theology cannot be reconciled with Islamic principle of monotheism without religious syncretism. Dixon, therefore highlights that, all the primary issues emerge from a lack of theological moorings and consequently a lack of a comprehensive biblical worldview, ${ }^{44}$ as well as a futile attempt to harmonize two opposing world-views whose their accompanying theological bases conflicts one another. Take for instance, the two master architects of contextualization Joshua Massey and John Travis use pseudonyms and report from unknown places about anonymous people. They quote what they claim to be authentic reports proving their theories but the reports are only accessible to a very few people on the pretext of security reason; like a survey made of what is called 'Islampur' people which is noted in journals but not revealed. ${ }^{45}$ Massey, on the other hand, advocates that Muslims do not necessarily need to understand and experience the Trinity because "not one biblical writer felt it necessary to extrapolate that God "is" Father, Son, and Holy Spirit..." ${ }^{46}$ Therefore, Jay sees this process as not only seductive but dangerous, as it leads to blindly adopting practices without looking at the long-term consequences to those practices. ${ }^{47}$ In narrating his personal experience he writes:

I have just returned from a Western country where a number of Western 'Christian' couples have chosen to voluntarily join their local Muslim community as hidden 'Christians' themselves. They have risen into positions of authority within this Muslim community, but, according to a Christian acquaintance, have now lost any view of Christ's divinity. If long standing Christians can so easily and quickly be seduced by the power of Islam, then why do we think the same will not happen to new believers? ${ }^{48}$

Still with respect to the practical and theological implications of contextualization, Christianity is filled with some vague

44 Roger L. Dixon, "Moving on from the C1-C6 Spectrum," St Francis Magazine, No. 5. Vol. IV (August 2009), 1.

45 Roger L. Dixon, "Moving on from the C1-C6 Spectrum," 5.

46 Roger L. Dixon, "Moving on from the C1-C6 Spectrum," 11.

47 Jay Smith, “An Assessment of Insider's Principle Paradigms," retrieved on 25 April 2014. http://www.answeringislam.org/fileadmin/authors/smith/insider_assessment. pdf, 2.

48 Jay Smith, “An Assessment of Insider's Principle Paradigms,” 4. 
theological issues such include the deity of Christ, the concept of Trinity, the atonement, death and resurrection of the Christ, the salvation and so on. All of these ideas are specifically rejected in the Qur'an while unfortunately they have invaded the church both practically and theologically. Therefore, how has the Christian mission responded to these practical theological challenges in the context of Muslim discipleship without distortion of Christianity? For instance, Islam rejects the idea of Original Sin, and therefore rejects the concept of atonement. Even when Muslims sacrifice an animal it is not an essential part of any theology of salvation from sin as in the case of the Christian blood of Christ. Hence, missionaries who perform solat [Muslim worship] will, by so doing stand against the whole theology of sacrifice for sin as essential to worshipping God. Practically, the idea of contextualization can be very appealing, but nevertheless it is deceptive, because by implication it teaches the theology it would rather reject. To sum up some of these implications of contextualization as follows:

Contextualization contradicts the theological teachings of the religion it propagates because the overriding idea in the scheme is to propagate Christianity through the lens of Islam: that instead of trying to get Muslims understand the Christian doctrine of trinity as it is, it will however be presented to them in a tauhidic form. It goes further to say that Muslims who decide to become Christians should stay within the fold of Islam, what they termed as Insider Movement. This is an outright distortion of religious dogma. In a simple question, how can the gospel operate within the context of Muslim without distortion? Defined as the theological process many non-Western churches were going through of reinterpreting the Gospel in terms of their own culture and situation in time, contextualization is simply a misrepresentation of doctrinal meanings of Christianity. By the way, it is a kind of religious syncretism. The differences in the fundamental beliefs and worldviews of both Islam and Christianity reveal that to contextualize the Gospel in Muslim society will rather lead to sheer syncretism of Christianity. In a tragic incidence reported by Andre Houssney a church was polarized Lebanon by a zealous missionary who insisted that members should call themselves "Muslim followers of Isa" instead of Christians, and another similar case in Jordan, where missionaries pressured a Christian man to deceitfully 
convert to Islam in order to marry a Muslim girl, an incident that tore the Church and the couple in two and caused a lot of damage. ${ }^{49}$

\section{Conclusion}

While some missionaries consider contextualization theologically erroneous on the part of the Christians, there are many Christian missiologists who challenged the traditional missionary approaches to Muslims as unproductive and accept the ideas of contextualization for indigenous, evangelistic, and culturally relevant church to emerge in the Islamic world-view. Moreover, in practical sense, taking into consideration some basic differences in the fundamental beliefs and world-views of Islam and Christianity, the contextualization of the later into the former cannot be done without distortion of the teaching of Christianity. However, despite reports showing that numerous Christian have lost the touch of Christ and became seduced by the power of Islam through joining their local Muslim community as hidden 'Christians,' the Muslims have a lot to do to check the progress of contextualization among them at least for the following two reasons: firstly, it has the tendency of misrepresenting Islam to some people that might affect some Muslims' thought and worldview in the long run. Secondly, it constitutes an infringement upon the right of Muslims over their religion which is distinct from other religions.

\section{Bibliography}

Azevado, S.J. Marcello Dec. "Workshop: Inculturation and the World Church". See website file://C:/Users/User/Downloads/3190-Article\%20Text5308-1-10-20130104\%20(1).pdf

Chastain, W. C. "Should Christians Pray the Muslim Salat?"International Journal of Frontier Mission, Vol. 7, no. 2 (JUL-SEP. 1995): 161.

ChukwumaOhajiriogu, Augustus. "Religion in the Context of African/Igbo Migration from the Pre-Colonial Times to the Contemporary Period". PhD. Thesis, University of Wien, 2009.

Corinthians.

49 Andre Houssney, "Ethical Implications of Contextualization," Evangelical Missiological Society, Rocky Mountain Meeting (April 3, 2009), 11. 
Danish, Ishtiyaq "Contextualization: A New Missionary Approach to Muslims," al-Tawhid, Vol. 5, no. 3 \& 4. Website www.alislam.org/altawhid/context.htm

Dixon, Roger L. "Moving on from the C1-C6 Spectrum," St Francis Magazine, No. 5. Vol. IV (August 2009), 1.

Emetche, Damian. "The Challenge of Discipling Muslim Background Believer." Website Global Missiology. Retrieved on 30 October 2014, www.GlobalMissiology.org.

Hadaway, Robin Dale. "Contextualization and Folk Islam: A Case Study of Sudan." PhD Thesis, University of South Africa, 2010.

Houssney, Georges. "Position Paper on the Insider Movement," website Journal of Biblical Missiology, http://biblicalmissiology.org/2010/05/03position-paper-oninsider-movement, 3.

Jay Smith, "An Assessment of Insider's Principle Paradigms." Retrieved on $25 \quad$ April 2014. http://www.answeringislam.org/fileadmin/authors/smith/insi der_assessment.pdf, 2.

John and Anna Travis, "Contextualization Among Muslims, Hindus and Buddhist: A Focus on Insider Movement," Mission Frontier, September-October 2005, website www.misionfrontiers.org

John and Anna Travis. "Contextualization among Muslims: A Focus on "Insider Movements" in Appropriate Christianity. William Carey Library Publishers, 2005.

Leffel, Jim. "Contextualization: Building Bridges to the Muslim Community," website Xenos Christian Fellowship. Retrieved on 20 August 2013, www.xenos.org/...ds/OnlineJournal/issue1/contextu.htm

Parshall, Phil. Muslim Evangelism: Contemporary Approaches to Contextualization. Waynesboro-USA: Gabriel Publishing, 2013.

Louersdorfs, Richard E. "Contextualization of the Gospel, What are the Implications of Our Work?" (World Mission Conference, East Fork, Arizona August 6-10, 1984). See http://essays.wisluthsem.org:8080/bitstream/handle/1234567 89/2905/LauersdorfGospel.pdf?sequence $=1$ \&isAllowed=y 
Stringer, John. "Contextualization: Transformational Trialogue," St Francis Magazine, June 2007, No 1. Vol. III, P2, website $\mathrm{http} / /$ :www.stfrancismagazine.info

Talman, Harley. "Islam, Once a Hopeless Frontier, Now? Comprehensive Contextualization," in International Journal of Frontier Mission. Retrieved on $15^{\text {th }}$ August 2013 www.ijfm.org/PDFs_IJFM/21_1_PDFs/06_12_Har Talman ley3.pdf.

Travis, John. "The C1 to C6 Spectrum: A Practical Tool for Defining Six Types of Christ-centered Communities (C) Found in the Muslim Context" in Evangelical Mission Quarterly (October 1998), pp. 407- 408, P. 6.

W. Eagle, Richard. "Contextualization in Missions: A Biblical and Theological Appraisal." Grace Theological Journal, Vol.4, no.1 (1983), 86.

Waldrep, Richard Brent. "Contextualization and Church Planting," Dissertation, The Southern Baptist Theological Seminary, 2007.

Warren-Rothlin, Andy. "Bible Translation and Evangelism in West Africa," Paper presented at the Kenya Translation Seminars, Pan-Africa Christian College (PACC), and all Saints Cathedrals, Nairobi, Kenya (June 2006), 6. 